\title{
Pregnancies after in-vitro fertilization of cow follicular oocytes, their incubation in rabbit oviduct and their transfer to the cow uterus*
}

\author{
M. A. Sirard $\dagger$, R. D. Lambert $\dagger \ddagger$, D. P. Ménard $\S$ and M. Bedoya $\S$ \\ $\dagger$ Laboratoire de Reproduction, CHUL, 2705 boul. Laurier, Ste-Foy, Québec, Canada GIV 4G2; \\ $\ddagger$ Département d'Obstétrique et Gynécologie, Faculté de Médecine, Université Laval, Québec, Canada \\ GIK 7 P4 and \$Clinique Vétérinaire Ste-Justine, Québec, Canada G0P 1 TO
}

\begin{abstract}
Summary. Cow embryos fertilized in vitro $(1-8$-cell) $(n=113)$ were transferred surgically to the ligated oviduct of pseudopregnant female rabbits $(31 \pm 4 \mathrm{~h}$ after 75 i.u. hCG). Rabbits were killed $99 \pm 5 \mathrm{~h}$ later and 67 embryos were recovered: 45 $(67 \%)$ had cleaved at least once, 15 had reached the morula stage and 2 blastocysts were obtained. Transfer of cleaved embryos (2-8-cell) led to a high recovery rate $(84 \%)$ compared to $39 \%$ for one-cell embryos. Of the embryos incubated for more than $99 \mathrm{~h}$ in the rabbit oviduct, $41 \%$ were at the morula stage. Embryos incubated in vivo $(n=21)$ (8-cell to blastocyst) were transferred to the uterus of 14 synchronized recipient heifers by a surgical $(\mathrm{N}=5)$ or a non-surgical $(\mathrm{N}=9)$ procedure: 6 pregnancies resulted ( 4 from the non-surgical procedures). In addition, 27 (2-8-cell) cow embryos developed in vitro were transferred to the oviduct of synchronized heifers by a paralumbar surgical approach on a standing animal, but no pregnancies resulted. It is therefore concluded that (1) the rabbit oviduct can be used to obtain cow eggs at an embryonic stage sufficiently advanced to permit transfer to the uterus of a synchronized recipient; and (2) the pregnancy rate after in-vitro fertilization and incubation in the rabbit oviduct are similar to results with fertilization in vivo.
\end{abstract}

\section{Introduction}

In-vitro fertilization was originally developed for the fundamental study of fertilization but more recently has been used clinically as a treatment for different kinds of human infertility problems. In cattle, this methodology has been helpful in research but the therapeutic applications have been limited by technical difficulties; there are reports of the birth of one calf in 1981 (Brackett et al., 1982) and two others in 1983 (Brackett, Keefer, Troop, Donawick \& Bennett, 1984). The surgical approach for the recovery of ova or for the transfer of embryos to the oviduct of recipients are the limiting factors to therapeutic utilization (Brackett, 1981; Wright \& Bondioli, 1981). Since that time a laparoscopic technique has been applied to cows (Lambert et al., 1983) and has increased the availability of mature follicular oocytes for in-vitro fertilization.

However, the development of in-vitro fertilized embryos is still limited in vitro to the pre-morula stage (Brackett et al., 1982; Bondioli \& Wright, 1983; Fukui, Fukushima \& Ono, 1983; Sugawara et al., 1984; Sirard, Lambert, Guay, Ménard \& Bedoya, 1985). Therefore, to evaluate the viability of embryos from in-vitro fertilization, an adequate development system is required.

The rabbit oviduct has been used for fertilization (Sreenan, 1970; Trounson, Willadsen \& Rowson, 1977; Hirst, DeMayo \& Dukelow, 1981; Dooley, Yorozu \& Bigin, 1983; Fukui et al.,

* Reprint requests to Dr R. D. Lambert. 
1983), capacitation (Iritani \& Niwa, 1977) and short-term development (Lawson, Rowson \& Adams, 1972; for review, see Boland, 1984) of cow gametes and embryos. The purpose of this study was to evaluate the oviduct of the rabbit as a temporary (4-5 days) incubator for in-vitro fertilized embryos of cows.

\section{Materials and Methods}

Animals. Holstein heifers $(\mathrm{N}=42)$ were used. They were monitored twice daily for signs of oestrus by using a testosterone-treated cow. The hormonal situation was begun 8-12 days after oestrus and consisted of a 4-day decreasing FSH treatment (FSH-P: Schering Canada, Pointe-Claire, Québec, Canada) (28 mg total in 8 injections). Luteolysis was induced by a cloprostenol injection (Estrumate: ICI Pharma, Mississauga, Ontario, Canada) $(500 \mu \mathrm{g}) 48 \mathrm{~h}$ after the first gonadotrophin injection. Standing oestrus for the donors was verified at 4-h intervals (except from 00:00 to 08:00 h) by using a bull with a surgically deflected penis (starting $36 \mathrm{~h}$ after cloprostenol injection). Animals were allowed to reach oestrus or were injected with 1500 i.u. luteinizing hormone (A.P.L.: Ayerst Laboratories, Montréal, Canada) $44 \mathrm{~h}$ after the cloprostenol injection. One Holstein bull provided the fresh semen.

Laparoscopy. Food and water were withheld for 12-18 h before laparoscopy. The technique for ovarian observation and follicular aspiration was as described by Lambert et al. (1983), and was used throughout this study. Laparoscopies were performed $24-25 \mathrm{~h}$ after hCG injection or estimated onset time of oestrus to obtain follicular oocytes as near as possible to ovulation. A recuperation time of 36 days (time for one natural oestrus) was allowed between two laparoscopies on the same animal. Recipients $(\mathrm{N}=27)$ were not used for laparoscopy.

Semen treatment. Fresh ejaculates were obtained from one single bull using an artificial vagina. Undiluted semen samples were first incubated for $2-3 \mathrm{~h}$ at $34^{\circ} \mathrm{C}$ with penicillin-G and streptomycin (Flow Laboratories, Virginia, U.S.A.) at a final concentration of $100 \mathrm{i} . \mathrm{u} . / \mathrm{ml}$ and $100 \mu \mathrm{g} / \mathrm{ml}$, respectively. After this incubation, $0.2 \mathrm{ml}$ semen was diluted with $4.8 \mathrm{ml}$ of high ionic-strength medium (Brackett, Evans, Donawick, Boice \& Cofone, 1980), incubated for $5 \mathrm{~min}$ at $37^{\circ} \mathrm{C}$, and then centrifuged for $5 \mathrm{~min}$ at $250 \mathrm{~g},\left(37^{\circ} \mathrm{C}\right)$. Supernatants were removed and spermatozoa were resuspended in $0.8 \mathrm{ml}$ defined medium (Brackett \& Oliphant, 1975) for an incubation of 3-18 h under an atmosphere of $5 \% \mathrm{CO}_{2}, 8 \% \mathrm{O}_{2}$ and $87 \%$ nitrogen $\left(3 \times 10^{7}-9 \times 10^{7}\right.$ spermatozoa $\left./ \mathrm{ml}\right)$. Spermatozoa were introduced in the fertilization drops at a final concentration of $1 \times 10^{6}$ cells $/ \mathrm{ml}$.

Oocyte treatment. Follicular oocytes were allowed to mature for 4-6 h in Brackett's defined medium before being transferred to the fertilization drops $(0.2 \mathrm{ml}$ defined medium under paraffin oil: Saybolt viscosity 125/135; Fisher Scientific, Fair Lawn, NJ, U.S.A.) for 12-20 h. After in-vitro fertilization, the zygotes were transferred immediately to the rabbit's oviduct or to growth medium (defined medium without albumin but supplemented with $10 \%(\mathrm{v} / \mathrm{v})$ heat-treated fetal calf serum) (Flow Laboratories; lot No. 29101051). All in-vitro incubations were carried out at $37^{\circ} \mathrm{C}$ with $5 \%$ $\mathrm{CO}_{2}$ in moist air. Embryos were examined twice daily for development until transfer.

In-vivo development. Individually caged female rabbits were induced to ovulate by an hCG injection (75i.u. A.P.L.: Ayerst Laboratories) and $24-36 \mathrm{~h}$ later they were anaesthetized with pentobarbitone sodium (Nembutal, $50 \mathrm{mg} / \mathrm{ml}$ : Abbott Laboratories, Montréal, Canada, H4P 1A5). A midventral approach was used to expose the oviducts. First, the ovaries were checked for the presence of newly formed corpora lutea and then the oviducts were ligated at about $1 \mathrm{~cm}$ from the uterus and the embryos were injected inside $(2-3 \mathrm{~cm})$ via the ampulla, using a slightly curved fire-polished pipette. After completion of the surgical procedure, the animals were individually caged for a mean time of $99 \pm 5 \mathrm{~h}$. The does were then killed and their oviducts were removed and flushed with $5 \mathrm{ml}$ Dulbecco's modified phosphate-buffered saline (PBS) with FCS $(20 \% \mathrm{v} / \mathrm{v})$ and 
antibiotics ( $50 \mathrm{i} . \mathrm{u}$. penicillin $/ \mathrm{ml}$ and $50 \mu \mathrm{g}$ streptomycin $/ \mathrm{ml}$.). The recovered embryos were washed once in PBS-FCS and then were examined under an inverted microscope. The embryos were transferred into the uterus of virgin heifers by a surgical or non-surgical embryo transfer procedures. Pregnancies were confirmed at 50 days by rectal palpation.

In addition, 27 2-8-cell embryos were transferred to the oviduct of synchronized recipient cows $(\mathrm{N}=13)$, using a standard paralumbar surgical approach. Surgery was done under local anaesthesia and embryos transferred to the oviduct ipsilateral to the corpus luteum. Synchronization was obtained by injection of $500 \mu \mathrm{g}$ cloprostenol $24 \mathrm{~h}$ before the injection given to the donor.

\section{Results}

After in-vitro fertilization, 621 -cell and 51 2-8-cell embryos were transferred to the oviducts of 17 pseudopregnant rabbits (Table 1). The results were assessed according to the initial stage of development. Cleaved embryos were not transferred into rabbits receiving uncleaved ova. Table 2 shows a higher recovery rate $(P<0.01)$ when $2-8$-cell eggs were transferred to the oviduct rather than 1-cell eggs. There was no significant difference in the developmental potential of 1-cell zygotes compared to cleaved embryos. Longer incubation resulted in greater losses of embryos (Table 3). However, a greater number of advanced embryos (16-cell and morula) were obtained (P1. 1, Figs 1, 2, 3, 4).

When in-vitro fertilized embryos $(\mathrm{N}=27)(2-8$-cell) were transferred to the oviduct of synchronized cows $(n=13)$ no pregnancies were obtained. Eleven of these recipient heifers were in

Table 1. In-vivo development in the rabbit oviduct of cow follicular oocytes fertilized in vitro

\begin{tabular}{lc}
\hline No. of embryos transferred (1-8-cell) & 113 (mean 6.6/female) \\
No. of embryos recovered & $67(67 / 13,60 \%)$ \\
No. of embryos that cleaved at least once & $45(45 / 67,67 \%)$ \\
No. of embryos that were at the 16-cell stage or more & $27(27 / 67,40 \%)$ \\
No. of recipients & 17 \\
Time after hCG injection (h) & $* 31 \cdot 2 \pm 4 \cdot 3$ \\
Incubation time (h) & $* 98 \cdot 8 \pm 5 \cdot 2$ \\
Embryo stage at transfer (cells) & $* 2 \cdot 04 \pm 1 \cdot 29$
\end{tabular}

* Mean \pm standard deviation.

Table 2. Influence of embryo stage at transfer upon in-vivo development in the rabbit oviduct of cow follicular oocytes fertilized in vitro

\begin{tabular}{|c|c|c|}
\hline & \multicolumn{2}{|c|}{ Embryo stage } \\
\hline & 1 cell & $\geqslant 2$ cells \\
\hline No. of embryos transferred & 62 & 51 \\
\hline No. of recipients & 6 & 11 \\
\hline No. of ova recovered $(\%)$ & $24(39)^{*}$ & $43(84)^{*}$ \\
\hline $\begin{array}{l}\text { No. of embryos with one cleavage or more } \\
\text { (\% of those recovered) }\end{array}$ & $15(62)$ & $30(70)$ \\
\hline $\begin{array}{l}\text { No. of embryos with } 16 \text {-cells or more } \\
\text { (\% of those recovered) }\end{array}$ & $12(50)$ & $15(35)$ \\
\hline $\begin{array}{l}\text { No. of morulae } \dagger \\
(\% \text { of those recovered })\end{array}$ & $7(29)$ & $8(19)$ \\
\hline
\end{tabular}


Table 3. Influence of incubation time upon in-vivo development in the rabbit oviduct of cow follicular oocytes fertilized in vitro

\begin{tabular}{|c|c|c|}
\hline & \multicolumn{2}{|c|}{ Incubation time } \\
\hline & $<99 \mathrm{~h} \dagger$ & $>99 \mathrm{~h} \ddagger$ \\
\hline No. of embryos transferred & 39 & 74 \\
\hline No. of females used & 6 & \\
\hline No. of embryos recovered (\%) & $30(77)^{*}$ & $37(50)^{*}$ \\
\hline $\begin{array}{l}\text { No. of embryos with one cleavage or more } \\
\text { (\% of those recovered) }\end{array}$ & $17(57)$ & $28(76)$ \\
\hline $\begin{array}{l}\text { No. of embryos with } 16 \text {-cells or more } \\
\text { ( } \% \text { of those recovered) }\end{array}$ & $7(23)$ & $20(56)$ \\
\hline $\begin{array}{l}\text { No. of morulae } \dagger \\
\quad(\% \text { of those recovered })\end{array}$ & 0 & $15(41)$ \\
\hline
\end{tabular}

oestrus the same day as the donor but 2 were detected in oestrus $24 \mathrm{~h}$ after the donor. All the embryos transferred to the uteri of recipient cows had been previously incubated in the rabbit oviduct. Embryonic development at the time of transfer to the uterus varied from 8-cell to blastocyst. Two methods were used for uterine transfer. For the surgical approach (laparotomy), 10 embryos ( 1 blastocyst, 7 morulae, 1 at 16 cells and 1 at 8 cells) were transferred to 5 cows, resulting in 3 pregnancies. One transfer was done with a blastocyst and a morula and has ended 55 days after transfer; all other pregnancies resulted from morulae (Table 4). For the non-surgical approach, 11 embryos ( 4 morulae, 5 at 16 cells and 2 at 8 cells) were transferred to 9 synchronized heifers, resulting in 4 pregnancies. In this latter group only one embryo was transferred to each heifer except for one heifer which received 3 embryos and became pregnant with twins. From the non-surgical transfer 4 pregnancies have resulted ( 2 from transfers of 16 -cell embryos and 2 from morulae). Out of 14 transfers to the uterus, therefore, 6 pregnancies have been maintained ( $>6$ months), giving a pregnancy rate of $43 \%$.

\section{Discussion}

The methodology described here permits normal development of in-vitro fertilized cow eggs from the 1-cell to the blastocyst stage equivalent in timing to that found in vivo. When fertilization and embryonic growth are performed in vitro, only a small proportion of eggs can reach the 16-cell stage. These results suggest that the in-vitro conditions used for fertilization and development are far from adequate. The viability, up to the morula stage, is markedly reduced (Table 2) after an in-vitro incubation of $48 \mathrm{~h}$, the time required for in-vitro fertilization and embryonic development to the 2-cell stage. This is in agreement with the results of Boland (1984) who showed a significant increase in the proportion of bovine eggs fertilized in vivo and developing at a normal rate in a rabbit oviduct with initial development going from 1-cell to morula.

Previous studies have shown that pregnancies could be obtained with embryos fertilized in vivo and incubated for up to 4 days in the rabbit oviduct (Lawson et al., 1972; Boland, 1984). In these studies, the results show no difference in the recovery of the embryos left for $24 \mathrm{~h}$ in the rabbit oviduct compared to $90-100 \mathrm{~h}$. The recovery rate obtained here (Table 3 ) is similar to that of others (Lawson et al., 1972; Boland, 1984) if the incubation in the rabbit's oviduct is less than $99 \mathrm{~h}$. However, if the incubation exceeds 4 days, the recovery rate is significantly lower but the proportion of 16-cell embryos is increased (Table 3). In addition, the oviduct seems to retain cleaved embryos 
PLATE 1
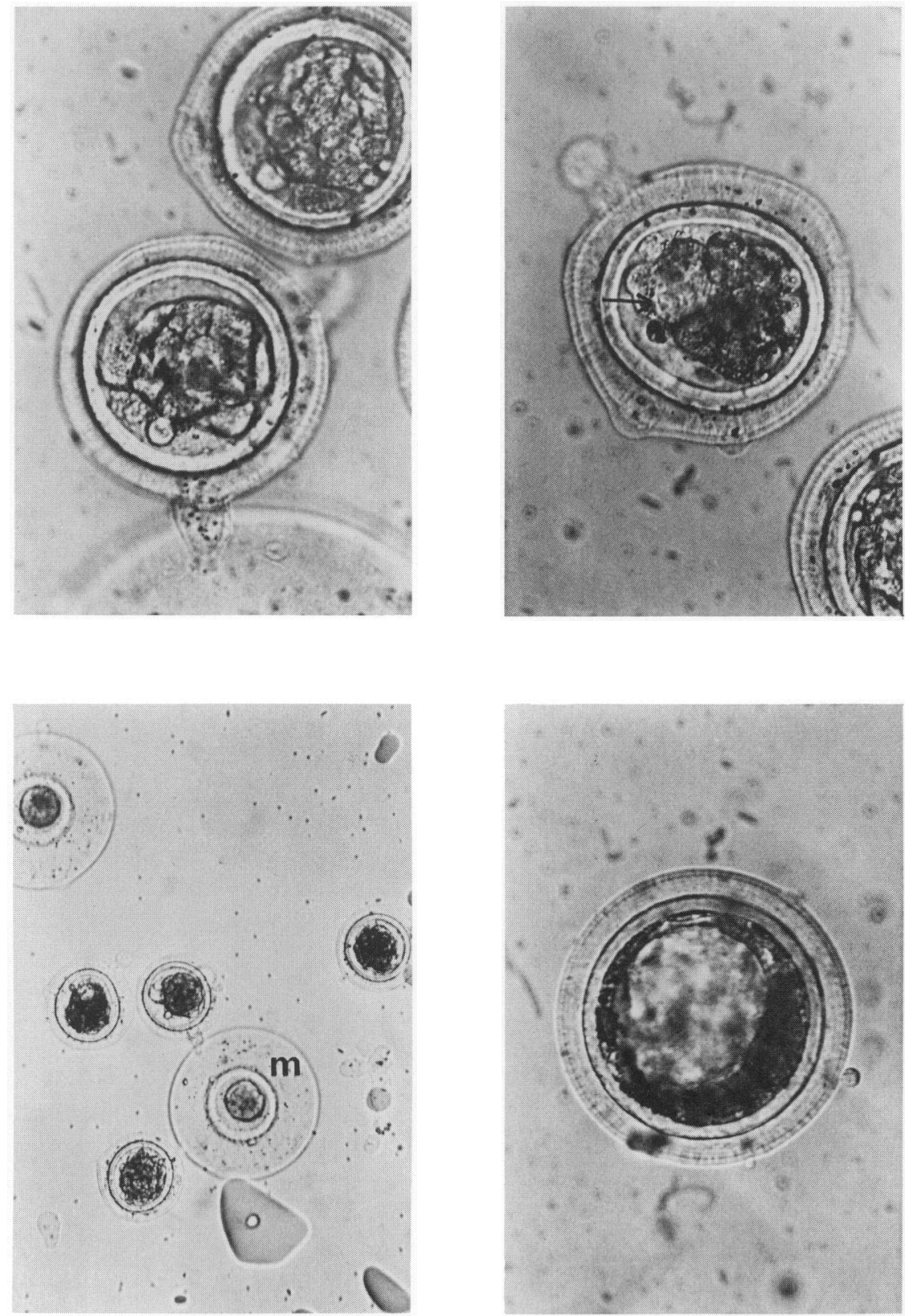

Fig. 1. Cow morulae after in-vitro fertilization and transfer at the 1-cell stage to the rabbit oviduct for $120 \mathrm{~h}(139 \mathrm{~h}$ after in-vitro insemination). $\times 250$.

Fig. 2. Cow morulae after in-vitro fertilization and transfer at the 1-cell stage into a rabbit oviduct for $120 \mathrm{~h}(139 \mathrm{~h}$ after in-vitro insemination). The blastocyst cavity has started to expand (arrow). $\times 250$.

Fig. 3. Same embryos as in Figs 1 and 2 but with rabbit eggs recovered from the same oviduct. Note the larger mucin layer $(\mathrm{m})$ on the rabbit eggs. $\times 90$.

Fig. 4. Cow blastocysts after in-vitro fertilization and transfer at the 2-4-cell stage into a rabbit oviduct for $118 \mathrm{~h}(168 \mathrm{~h}$ after in-vitro insemination). $\times 250$.

(Facing p. 554) 
Table 4. In-vivo development of in-vitro fertilized cow embryos after incubation in the rabbit oviduct and transfer to the uterus of virgin heifers

\begin{tabular}{lccccc}
\hline & Recipients & $\begin{array}{c}\text { No. of } \\
\text { embryos }\end{array}$ & $\begin{array}{c}\text { Next } \\
\text { oestrus (days) }\end{array}$ & Pregnancies & $(\%)$ \\
\hline Surgical transfer & 5 & 10 & $31 \pm 4$ & $2^{*}$ & $(40)$ \\
Non-surgical transfer & 9 & 11 & $21 \pm 2$ & $4 \dagger$ & $(44)$ \\
\hline
\end{tabular}

* Does not include one female that aborted 55 days after transfer.

t One of the recipients is carrying twins.

more efficiently than uncleaved ones (Table 2). This difference could be explained by the number of eggs injected in the females; a mean number of $10.3 \pm 2.8$ for the 1-cell and $4.6 \pm 2.0$ for the 2-8-cell stages were transferred into each doe. But this explanation would be in contrast with the results of Hirst et al. (1981) who reported a higher recovery rate with a larger number of mouse embryos transferred in the rabbit oviduct. This could indicate that a signal from the fertilized egg influences its retention. This would be in agreement with our observation that $75 \%$ of the unfertilized rabbit ova were not recovered after flushing the ligated oviduct (compared to the number of corpora lutea). In addition, the results presented here suggest that cleaved embryos are recovered in larger proportion (Table 2) and the more time they spend in the oviduct, the higher is the proportion of retained embryos that are cleaved. Incubations longer than 4 days led to recovery of $41 \%$ morulae (Table 3 ).

The mucin coat found on cow embryos (PI. 1, Figs 1-4) does not seem to impair subsequent development (this study; Lawson et al., 1972; Boland, 1984) even when hatching is not observed in vitro with in-vivo fertilized blastocysts incubated in the rabbit oviduct (Boland, 1984). The amount of mucin on cow embryos is about 5 times less than that on rabbit eggs (P1. 1, Fig. 4) but is similar to that found round surrogate glass eggs (Bourdage \& Halbert, 1984).

The rabbit oviduct can support normal development of cow embryos as proved by the pregnancies obtained from transfers of 1-cell $(\mathrm{N}=2)$, 2-cell $(\mathrm{N}=2), 4-6$-cell $(\mathrm{N}=2)$ embryos and embryos incubated less than $99 \mathrm{~h}(\mathrm{~N}=3)$ or more than $99 \mathrm{~h}(\mathrm{~N}=3)$ in the present study. This confirms the studies of Lawson et al. (1972) and those of Boland (1984) showing that the normal appearance and, most probably more important, the right timing of development at the end of the rabbit oviduct incubation give a good chance of embryo implantation in recipient heifers.

A long enough incubation in the rabbit oviduct will permit the embryo to reach the morula stage. Uterine transfer has three important advantages: (1) fewer recipients are needed because of the selective effect of the rabbit oviduct; (2) transfers can perhaps be performed at the farm; and (3) there is a higher pregnancy rate after transfer to the uterus than to the oviduct of heifers. The lower rate with oviducal transfers could be explained by the surgical approach which may result in greater mechanical tension on the oviduct and the ovary.

With this methodology it is theoretically possible to obtain one pregnancy every 2 or 3 laparoscopies. Previous results (Lambert, Sirard \& Béland, 1984; Sirard et al., 1985) have shown that $7 \cdot 4 \pm 4 \cdot 1$ oocytes are recovered per animal after laparoscopy. From those, $68 \%$ are with an expanded cumulus (5 oocytes/cow) and will reach the 2 -cell stage at a $60 \%$ rate ( 3 embryos/cow). When cleaved embryos are transferred in the rabbit, $84 \%$ are recovered $(2.5 / \mathrm{cow})$ and $35 \%$ are at the $\geqslant 16$-cell stage $(0 \cdot 9$ embryo/cow) which can lead to pregnancies in 6 out of 14 cows $(43 \%)$ ( 0.4 embryo/cow).

In conclusion, the results presented in this study indicate that the rabbit oviduct could be useful to evaluate the effects of procedures such as in-vitro fertilization in the cow. It could also be applied to remedy infertility in cows due to various causes.

Funding was provided by Agriculture Canada (0SV-00095) and MAPAQ (LM 80-817). 


\section{References}

Boland, M.P. (1984) Use of the rabbit oviduct as a screening tool for the viability of mammalian eggs. Theriogenology 21, 127-137.

Bondioli, K.R. \& Wright, R.W., Jr (1983) In vitro fertilization of bovine oocytes by spermatozoa capacitated in vitro. J. Anim. Sci. 57, 1001-1005.

Bourdage, R.J. \& Halbert, S.A. (1984) Quantification of intraluminal motion of surrogate ova in the rabbit oviductal isthmus. Biol. Reprod. 30, 1124-1129.

Brackett, B.G. (1981) Applications of in vitro fertilization. In New Technologies in Animal Breeding, pp. 141-161. Eds B. G. Brackett, G. E. Seidel Jr \& S. M. Seidel. Academic Press, New York.

Brackett, B.G. \& Oliphant, G. (1975) Capacitation of rabbit spermatozoa in vitro. Biol. Reprod. 12, 260-274.

Brackett, B.G., Evans, J.F., Donawick, W.J., Boice, M.L. \& Cofone, M.A. (1980) In vitro penetration of cow oocytes by bull sperm. Archs Androl. 5, 69-71.

Brackett, B.G. Bousquet, D., Boice, M.L., Donawick, W.J., Evans, J.F. \& Dressel, M.A. (1982) Normal development following in vitro fertilization in the cow. Biol. Reprod. 27, 147-158.

Brackett, B.G., Keefer, C.L., Troop, C.G., Donawick, W.J. \& Bennett, K.A. (1984) Bovine twins resulting from in vitro fertilization. Theriogenology 21, 224, Abstr.

Dooley, V.D., Yorozu, Y. \& Bigin, F. (1983) Bovine oocyte in vitro maturation and xenogenous fertilization. Biol. Reprod. 28, Suppl. 1, 116, Abstr.

Fukui, Y., Fukushima, M. \& Ono, H. (1983) Fertilization of bovine oocytes after various sperm procedures. Theriogenology 20, 651-660.

Hirst, P.J., DeMayo, F.J. \& Dukelow, W.R. (1981) Xenogenous fertilization of laboratory and domestic animals in the oviduct of the pseudopregnant rabbit. Theriogenology 15, 67-75.

Iritani, A. \& Niwa, K. (1977) Capacitation of bull spermatozoa and fertilization in vitro of cattle follicular oocytes matured in culture. J. Reprod. Fert. 50, 119-121.
Lambert, R.D., Bernard, C., Rioux, J.E., Béland, R., D'Amours, D. \& Montreuil, A. (1983) Endoscopy in cattle by the paralumbar route: technique for ovarian examination and follicular aspiration. Theriogenology 20, 149-161.

Lambert, R.D., Sirard, M.A. \& Béland, R. (1984) The fertilization performance in vitro of bovine and rabbit spermatozoa capacitated in vitro. Proc. 10th Int. Congr. Anim. Reprod. \& A.I., Urbana, vol. III, 392, brief comm.

Lawson, R.A.S., Rowson, L.E.A. \& Adams, C.E. (1972) The development of cow eggs in the rabbit oviduct and their viability after re-transfer to heifers. $J$. Reprod. Fert. 28, 313-315.

Sirard, M.A., Lambert, R.D., Guay, P., Ménard, D.P. \& Bedoya, M. (1985) In vivo and in vitro development of in vitro fertilized bovine follicular oocytes obtained at laparoscopy. Theriogenology 23, 230, Abstr.

Sreenan, J. (1970) In vitro maturation and attempted fertilization of cattle follicular oocytes. J. agric. Sci., Camb. 75, 393-396.

Sugawara, S., Hamano, K., Miyamoto, A., Kameyama, K., Horiuchi, T. \& Masaki, J. (1984) In vitro fertilization and subsequent development of bovine oocytes precultured in synthetic media. Proc. 10th Int. Congr. Anim. Reprod. \& A.I., Urbana, vol. III, 382, brief comm.

Trounson, A.O., Willadsen, S.M. \& Rowson, L.E.A. (1977) Fertilization and development capability of bovine follicular oocytes matured in vitro and in vivo and transferred to the oviducts of rabbit and cows. $J$. Reprod. Fert. 51, 32I-327.

Wright, R.W., Jr \& Bondioli, K.R. (1981) Aspects of 'in vitro' fertilization and embryo culture in domestic animals. J. Anim. Sci. 53, 702-729. 